\title{
PERBEDAAN POLA RESISTENSI Staphylococcus koagulase negatif ISOLAT DARAH TERHADAP ANTIBIOTIKA DI RSU Dr SAIFUL ANWAR MALANG TAHUN 2000-2001 DENGAN 2004-2005
}

\section{THE DIFFERENCE of ANTIBIOTICS RESISTANCE PATTERN OF Coagulase negative Staphylococci FROM BLOOD ISOLATE IN DR. SAIFUL ANWAR GENERAL HOSPITAL IN MALANG DURING THE YEAR OF 2000-2001 AND 2004-2005}

\author{
Sjoekoer M. Dzen, Sanarto Santoso, Roekistiningsih, Dewi Santosaningsih \\ Laboratorium Mikrobiologi Fakultas Kedokteran Universitas Brawijaya / RSU dr .Saiful Anwar Malang
}

\begin{abstract}
Coagulase negative staphylococci (CoNS) are the common bacterias causing hospital-acquired infection manifested as bacteremia. The antibiotics therapy against bacterial infection is mostly empiric, whereas the bacterial pattern and its sensitivity to antibiotics differ between region and from year to year. The objective of this study was to determine the changes of prevalence and antibiotics sensitivity pattern of CoNS, the etiologic agent of bacteremia in patients hospitalised in Dr.Saiful Anwar General Hospital, Malang. Culture and antibiotic sensitivity test were performed on 650 and 1063 blood samples during the year of 2000-2001 and 2004-2005 respectively in the Laboratory of Microbiology, Faculty of Medicine, Brawijaya University / Dr.Saiful Anwar General Hospital in Malang following NCCLS 1997. ChiSquare test was used to analysed of data. The result of this study revealed that the CoNS was the most isolate found in the blood samples and its resistance to beta lactam antibiotics tends to increase statistically.
\end{abstract}

Key words: Coagulase negative staphylococci, antibiotics sensitivity pattern

\section{PENDAHULUAN}

Staphylococcus koagulase negatif saat ini diakui sering menyebabkan infeksi nosokomial terutama dalam bentuk bakteremia pada penderita neonatus, penderita immunocompromised, dan penderita dengan indwelling prosthetic devices $(1,2)$. Pfaller (1998) menyatakan bahwa di lowa, Staphylococcus koagulase negatif merupakan penyebab ketiga bakteremia setelah Staphylococcus aureus dan Escherichia coli. The European prevalence of infection in intensive care (EPIC) study di Eropa menunjukkan prevalensi infeksi Staphylococcus koagulase negatif sebanyak $44,9 \%$ di unit perawatan intensif yang terkait dengan pemasangan kateter intravena. Angka kematian infeksi yang disebabkan oleh bakteri tersebut berkisar 18,5 $-57 \%$ (3).

Di banyak rumah sakit negara maju, jika suatu penyakit infeksi diduga disebabkan oleh Staphylococcus koagulase negatif, maka terapi yang diberikan kepada penderita dilakukan berdasarkan pengalaman empirik berupa antibiotika dari golongan glikopeptida. Namun penggunaan berlebihan terhadap antibiotika tersebut menyebabkan timbulnya resistensi bakteri (2). Demikian pula halnya dengan di Indonesia, pemberian terapi

Jurnal Kedokteran Brawijaya, Vol. XXI, No.3, Desember 2005 Korespondensi: Sjoekoer M. Dzen; Laboratorium Mikrobiologi Fakultas Kedokteran Unibraw; JI. Veteran Malang 65145; Telp. (0341) 580993 ext. 111 antibiotika terhadap suatu penyakit infeksi bakterial sebagian besar dilakukan berdasar pada pengalaman empirik masa lalu atau pada rekomendasi dari jurnal luar negeri, tidak berdasar pada hasil uji resistensi terhadap antibiotika. Hal yang demikian itu tidak dapat dibenarkan mengingat pola bakteri penyebab penyakit infeksi dan pola resistensinya terhadap antibiotika berbeda antara satu daerah dengan daerah lain dan berbeda pula dari waktu ke waktu. Penggunaan antibiotika secara tidak rasional tersebut memicu terjadinya resistensi bakteri.

Penelitian ini bertujuan untuk mengetahui perbedaan prevalensi Staphylococcus koagulase negatif sebagai penyebab bakteremia pada penderita yang dirawat di RSUD dr.Saiful Anwar Malang, dan perbedaan pola resistensinya terhadap antibiotika secara invitro, sehingga dapat digunakan sebagai referensi dalam terapi penyakit infeksi yang disebabkan oleh Staphylococcus koagulase negatif.

\section{METODE}

Penelitian dilakukan secara retrospektif. Sampel penelitian ini berupa sampel darah penderita yang dikirim ke Laboratorium Mikrobiologi Fakultas Kedokteran Universitas Brawijaya/RSUD dr. Saiful Anwar Malang dengan perincian 650 sampel darah pada tahun 2000-2001 dan 1063 sampel darah pada tahun 2004-2005.

Sampel darah diambil dengan pungsi vena perifer secara aseptik. Semua sampel darah dilakukan kultur pada medium bifasik-BHI (Brain Heart Infusion) hingga 10-14 hari 
pada suhu $37^{\circ} \mathrm{C}$ dengan dilakukan pengamatan setiap 2 hari sekali untuk mendeteksi adanya pertumbuhan bakteri. Bila ada pertumbuhan dilakukan subkultur pada medium agar Mueller Hinton. Selanjutnya dilakukan identifikasi bakteri berdasarkan hasil pewarnaan Gram.

Identifikasi bakteri kokus Gram positif dilakukan dengan uji katalase dan koagulase. Sedangkan identifikasi bakteri batang Gram negatif dilakukan dengan uji oksidase terlebih dahulu yang diikuti dengan uji biokimia menggunakan microbact system.

Tahap selanjutnya adalah uji resistensi antimikroba menggunakan metode difusi cakram sesuai National Committee for Clinical Laboratory Standards (NCCLS) 1997. Cakram antibiotika yang digunakan adalah penisilinG, ampisilin, amoksisilin+asam klavulanat, sefotaksim, seftriakson, sefuroksim, sefalotin, gentamisin, amikasin, netilmisin, ofloksasin, norfloksasin, tetrasiklin, kloramfenikol, doksisiklin, eritromisin, dan kotrimoksasol (4).

\section{Analisis Statistik}

Perbedaan pola resistensi Staphylococcus koagulase negatif terhadap antibiotika pada periode penelitian yang berbeda dianalisis dengan uji ChiSquare Sedangkan perbedaan pola resistensi bakteri tersebut terhadap antibiotika yang berbeda pada periode penelitian yang sama dianalisis dengan uji Krusak Wallis. Kedua uji statistik tersebut dilakukan menggunakan perangkat lunak SPSS versi 10.0 .

\section{HASIL PENELITIAN}

Hasil kultur darah penderita yang dikirim ke Laboratorium Mikrobiologi FK Unibraw / RSSA pada tahun 2000-2001 menunjukkan bahwa dari 650 sampel darah yang dikirim diperoleh 86 sampel kultur positif $(13,02 \%)$ dan sisanya kultur negatif. Sedangkan hasil kultur darah pada tahun 2004-2005 menunjukkan bahwa dari 1063 sampel darah yang dikirim diperoleh 82 sampel kultur positif $(7,7 \%)$ dan sisanya kultur negatif (Gambar1).

Jenis isolat bakteri yang teridentifikasi dari 86 sampel kultur positif pada tahun 2000-2001 berturut-turut: Staphylococcus koagulase negatif (22\%), Staphylococcus aureus (15\%), Klebsiella pneumoniae (15\%), Acinetobacter anitratus (15\%), Enterobacter aerogenes (9\%), Enterobacter gergoviae (8\%), Escherichia coli (7\%), Pseudomonas aeruginosa (5\%), Citrobacter freundii (2\%), Salmonella typhi (1\%), dan Enterobacter agglomerans (1\%). Sedangkan jenis isolat bakteri yang diperoleh dari 82 sampel kultur positif pada tahun 2004-2005 berturut-turut: Staphylococcus koagulase negatif (18\%), Enterobacter aerogenes (15\%), Klebsiella pneumoniae (12\%), Hafnia alvei (12\%), Staphylococcus aureus (10\%), Enterobacter gergoviae (10\%), Acinetobacter anitratus (5\%), Pseudomonas aeruginosa (4\%), dan Escherichia coli, Klebsiella oxytoca, Klebsiella ozaenae, Pseudomonas fluorescens, Salmonella typhi, Serratia liquefaciens, Yersinia pseudotuberculosis masing-masing 2\% (Gambar 2).

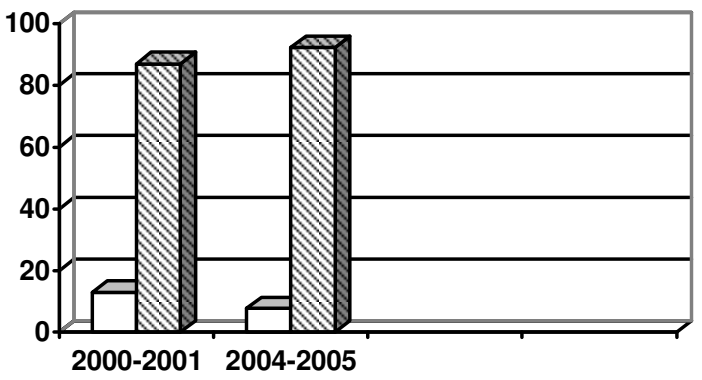

\section{Gambar 1.Hasil Kultur Darah di Laboratorium Mikrobiologi FK Unibraw / RSSA Malang Tahun 2000-2001 dan 2004-2005}




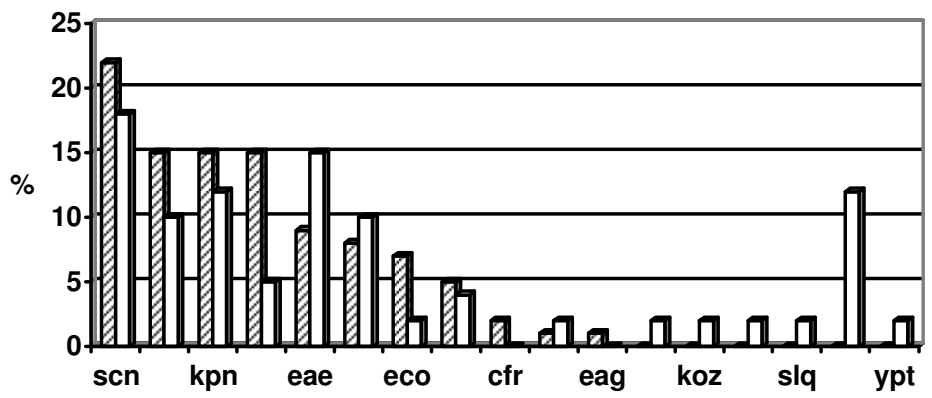

\section{Gambar 2. Prevalensi Isolat Bakteri Hasil Kultur Darah di Laboratorium Mikrobiologi FK Unibraw / RSSA Tahun 2000-2001 dan 2004-2005.}

Keterangan:

scn = Staphylococcus koagulase negatif

sau = Staphylococcus aureus

$\mathrm{kpn}=$ Klebsiella pneumoniae

aan $=$ Acinetobacter anitratus

sty = Salmonella typhi

eag $=$ Enterobacter agglomerans

eae $=$ Enterobacter aerogenes

kox = Klebsiella oxytoca

koz = Klebsiella ozaenae

egg = Enterobacter gergoviae

pfl = Pseudomonas fluorescens

eco $=$ Escherichia coli

pae = Pseudomonas aeruginosa

cfr = Citrobacter freundii

slq $=$ Serratia liquefaciens

hal = Hafnia alvei

ypt $=$ Yersinia pseudotuberculosis

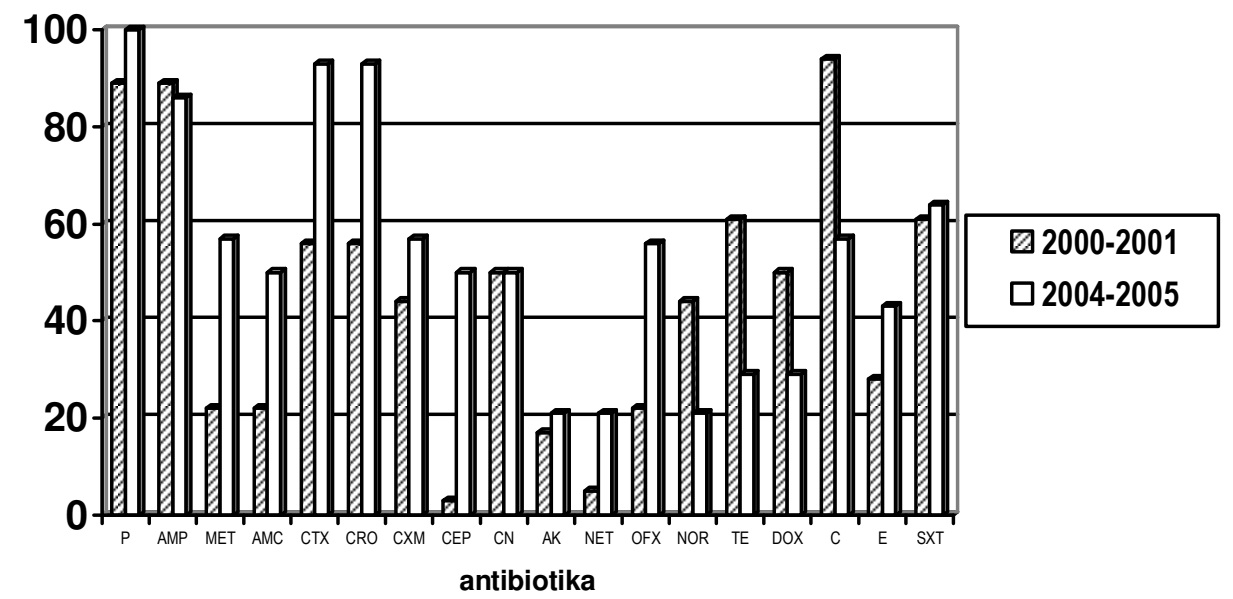

Gambar 3. Pola Resistensi Staphylococcus Koagulase Negatif Isolat Darah Terhadap Antibiotika Tahun 2000-2001 dan 2004-2005

Keterangan :

$\begin{array}{lllll}\text { P } & \text { Penisilin } & \text { AK } & \text { Amikasin } \\ \text { AMP } & : \text { Ampisilin } & \text { NET } & \text { Netilmisin } \\ \text { MET } & \text { Metisilin } & \text { OFX } & \text { : Ofloksasin } \\ \text { AMC } & : \text { Amoksisilin + asam klavulanat } & \text { NOR } & : \text { Norfloksasin } \\ \text { CTX } & : \text { Sefotaksim } & \text { TE } & : \text { Tetrasiklin } \\ \text { CRO } & : \text { Seftriakson } & \text { DOX } & \text { : Doksisiklin } \\ \text { CXM } & : \text { Sefuroksim } & \text { C } & : \text { Kloramfenikol } \\ \text { CEP }: \text { Sefalotin } & \text { E } & : \text { Eritromisin } \\ \text { CN }: \text { Gentamisin } & \text { SXT }: \text { Kotrimoksasol }\end{array}$


Hasil uji resistensi terhadap antibiotika pada penelitian ini difokuskan pada bakteri Staphylococcus koagulase negatif. Pada tahun 2000-2001 hasil uji resistensi 18 isolat Staphylococcus koagulase negatif terhadap antibiotika menunjukkan resistensi yang relatif rendah terhadap amoksisilin+asam klavulanat (22\%), amikasin $(17 \%)$, netilmisin $(6 \%)$, dan ofloksasin $(23 \%)$. Pada tahun 2004-2005, hasil uji resistensi 14 isolat Staphylococcus koagulase negatif terhadap antibiotika menunjukkan resistensi yang relatif rendah terhadap amikasin $(21 \%)$, netilmisin $(21 \%)$, norfloksasin $(21 \%)$, tetrasiklin $(29 \%)$, dan doksisiklin (29\%) (Gambar 3).

Dengan menggunakan uji ChiSquare didapatkan bahwa secara statistik terdapat peningkatan resistensi terhadap seluruh antibiotika yang diujikan dari tahun 2000 2001 dan tahun 2004-2005 ( $\left.X^{2}=58,207 ; p<0,05\right)$. Kontribusi peningkatan resistensi tersebut terutama diperankan oleh antibiotika beta laktam (penisilin-G, ampisilin, amoksisilin + asam klavulanat, metisilin, sefotaksim, seftiakson, sefuroksim, dan sefalotin) dengan $X^{2}=13,785 \quad p<0,05$. Sedangkan peningkatan resistensi antibiotika golongan lain tidak terlalu tajam sehingga tidak bermakna secara statistik. Selain peningkatan resistensi, terdapat penurunan resistensi yang terjadi pada antibiotika norfloksasin, tetrasiklin, doksisiklin, dan kloramfenikol (Tabel 1).

Dengan menggunakan uji Kruskal Wallis didapatkan bahwa secara statistik pada periode tahun 2000-2001 tidak terdapat perbedaan bermakna pola resistensi antara antibiotika golongan beta laktam, dengan golongan aminoglikosida, golongan quinolon, golongan tetrasiklin dan golongan lain yang diujikan terhadap kuman Staphylococcus koagulase negatif $\left(X^{2}=5,352 ; p>0,05\right)$. Sedangkan pada periode tahun 2004-2005 ternyata terdapat perbedaan bermakna pola resistensi antara antibiotika golongan beta laktam, dengan golongan aminoglikosida, golongan quinolon, golongan tetrasiklin dan golongan lain yang diujikan terhadap kuman Staphylococcus koagulase negatif $\left(X^{2}=9,778 ; p<0,05\right)$.
Tabel1. Hasil Uji Resistensi Staphylococcus koagulase negatif Isolat Darah Terhadap Antibiotika Tahun 2000-2001 dan 2004-2005

\begin{tabular}{lcccc}
\hline \multirow{2}{*}{ Antibiotika } & \multicolumn{2}{c}{$\begin{array}{c}\text { Tahun 2000-2001 } \\
\text { (n=18) }\end{array}$} & \multicolumn{2}{c}{ Tahun 2004-2005 } \\
\cline { 2 - 5 } & $\%$ (n=14) \\
\hline Penisilin-G & $11 \%$ & $89 \%$ & $0 \%$ & $100 \%$ \\
\hline Ampisilin & $11 \%$ & $89 \%$ & $14 \%$ & $86 \%$ \\
\hline Metisilin & $78 \%$ & $22 \%$ & $43 \%$ & $57 \%$ \\
\hline Amoksisilin+asam & $78 \%$ & $22 \%$ & $50 \%$ & $50 \%$ \\
klavulanat & & & & \\
\hline Sefotaksim & $44 \%$ & $56 \%$ & $7 \%$ & $93 \%$ \\
\hline Seftriakson & $44 \%$ & $56 \%$ & $7 \%$ & $93 \%$ \\
\hline Sefuroksim & $56 \%$ & $44 \%$ & $43 \%$ & $57 \%$ \\
\hline Sefalotin & $67 \%$ & $33 \%$ & $50 \%$ & $50 \%$ \\
\hline Gentamisin & $50 \%$ & $50 \%$ & $50 \%$ & $50 \%$ \\
\hline Amikasin & $83 \%$ & $17 \%$ & $79 \%$ & $21 \%$ \\
\hline Netilmisin & $95 \%$ & $5 \%$ & $79 \%$ & $21 \%$ \\
\hline Ofloksasin & $78 \%$ & $22 \%$ & $64 \%$ & $56 \%$ \\
\hline Norfloksasin & $56 \%$ & $44 \%$ & $79 \%$ & $21 \%$ \\
\hline Tetrasiklin & $39 \%$ & $61 \%$ & $71 \%$ & $29 \%$ \\
\hline Doksisiklin & $50 \%$ & $50 \%$ & $71 \%$ & $29 \%$ \\
\hline Kloramfenikol & $6 \%$ & $94 \%$ & $43 \%$ & $57 \%$ \\
\hline Eritromisin & $72 \%$ & $28 \%$ & $57 \%$ & $43 \%$ \\
\hline Kotrimoksasol & $39 \%$ & $61 \%$ & $36 \%$ & $64 \%$ \\
\hline
\end{tabular}

\section{DISKUSI}

Staphylococcus koagulase negatif terdiri dari beberapa spesies seperti Staphylococcus epidermidis, Staphylococcus haemolyticus, Staphylococcus hominis, Staphylococcus warner dll $(5,6,7)$. Oleh karena keterbatasan fasilitas, maka pada penelitian ini tidak dilakukan identifikasi lebih lanjut spesies Staphylococcus koagulase negatif yang sudah diperoleh. Namun menurut penelitian Giusti (1999), Staphylococcus epidermidis merupakan spesies yang dominan dari seluruh isolat Staphylococcus koagulase negatif yang ditemukan (1).

Hasil penelitian ini menunjukkan bahwa pada 2 periode penelitian yaitu pada tahun 2000-2001 dan 20042005, prevalensi Staphylococcus koagulase negatif tetap paling tinggi di antara sejumlah bakteri yang dapat diidentifikasi dari kultur positif sampel darah penderita yang dikirim ke Laboratorium Mikrobiologi FK Unibraw / RSSA Malang. Penelitian lebih lanjut sangat dibutuhkan untuk menentukan apakah Staphylococcus koagulase negatif dari isolat darah tersebut berasal dari infeksi di komunitas atau merupakan infeksi nosokomial, karena menurut beberapa peneliti Staphylococcus koagulase negatif sering menyebabkan infeksi nosokomial pada penderita dengan indwelling catheters yang sebenarnya sangat mungkin untuk dicegah $(3,6,8)$. Perlu diperhatikan juga bahwa angka infeksi nosokomial di Indonesia berdasarkan survei sederhana (point prevalence) yang dilakukan oleh Subdit 
Surveillance Ditjen PPM \& PLP di 10 rumah sakit umum pendidikan tahun 1987 rata-rata $9,8 \%$ dengan rentang 6 $16 \%$ (9). Infeksi nosokomial yang disebabkan oleh Staphylococcus koagulase negatif sangat mungkin terjadi karena menurut hasil penelitian Lilik Z, (2004), dari 4 perawat ruangan ICU dan CVC yang telah mencuci tangannya saat akan melakukan tindakan ternyata 3 orang membawa bakteri Staphylococcus epidermidis. Infeksi nosokomial yang disebabkan oleh Staphylococcus koagulase negatif ini semakin menjadi rumit karena bakteri tersebut seringkali resisten terhadap penicillinase-resistant penicillins oksasilin atau metisilin, dan hal ini mengindikasikan resistensi silang terhadap semua antibiotika golongan beta laktam termasuk antibiotika golongan sefalosporins (1).

Berbeda dengan hasil program surveilans antimikroba (SENTRY Antimicrobial Program) di Amerika Serikat dan Kanada tahun 1997 yang menunjukkan bahwa frekuensi Staphylococcus koagulase negatif menempati urutan ke-3 dari seluruh isolat bakteri penyebab blood stream infection (BSI). Sedangkan Staphylococcus aureus dan Escherichia coli masing-masing berada di urutan pertama dan kedua (10). Fakta ini membuktikan bahwa pola isolat bakteri penyebab penyakit infeksi berbeda antara satu daerah dengan daerah yang lain.

Hasil uji resistensi Staphylococcus koagulase negatif terhadap antibiotika pada 2 periode penelitian ini menunjukkan perubahan pola resistensi bakteri tersebut terhadap berbagai antibiotika. Hal yang paling penting untuk diperhatikan adalah bahwa terdapat peningkatan resistensi bakteri terhadap metisilin dimana pada tahun 2000-2001 terdapat 22\% Staphylococcus koagulase negatif yang resisten terhadap metisilin sedangkan pada tahun 20042005 meningkat hingga 57\%. Fakta ini diikuti dengan peningkatan resistensi bakteri Staphylococcus koagulase negatif terhadap antibiotika penisilin-G dan ampisilin serta antibiotika golongan sefalosporins yaitu sefotaksim, seftriakson, sefuroksim, dan sefalotin. Bahkan peningkatan resistensi bakteri ini sangat tajam terjadi terhadap antibiotika golongan sefalosporins generasi ketiga yaitu sefotaksim dan seftriakson (Tabel 1). Resistensi bakteri terhadap metisilin atau oksasilin ini perlu diwaspadai karena menyebabkan dampak negatif pada meningkatnya tingkat morbiditas dan mortalitas, serta meningkatnya kesempatan penyebaran penyakit akibat kegagalan terapi (1). Hasil yang sama diperoleh pada penelitian Cuevas et al. (2004) yang menunjukkan peningkatan resistensi Staphylococcus koagulase negatif terhadap oksasilin antara tahun 1986 sampai 2002 di 5 daerah di Spanyol dari 32,5\% meningkat hingga 61,3\% (11). Sedangkan hasil SENTRY Antimicrobial Surveillance Program pada tahun 1997 menunjukkan angka resistensi Staphylococcus koagulase negatif terhadap oksasilin di Amerika Serikat sebesar 56,9\% dan di Kanada sebesar $52,2 \%(10)$.

Selain terjadi peningkatan resistensi bakteri Staphylococcus koagulase negatif terhadap antibiotika golongan penisilin dan derivatnya serta golongan sefalosporins, ternyata terdapat juga peningkatan resistensi bakteri tersebut terhadap antibiotika golongan aminoglikosida yaitu netilmisin, dan amikasin. Namun demikian peningkatan resistensi yang terjadi tidak terlalu tajam, data menunjukkan $79 \%$ bakteri Staphylococcus koagulase negatif masih sensitif terhadap kedua antibiotika tersebut, sehingga masih mungkin untuk digunakan sebagai terapi walaupun dengan kelemahan jika ditinjau dari sisi harga dan keamanan farmakokinetiknya khususnya bagi pasien anak.

Resistensi bakteri Staphylococcus koagulase negatif terhadap eritromisin juga mengalami peningkatan. Antibiotika ini seringkali direkomendasikan pada pasien yang mengalami reaksi hipersensitivitas terhadap antibiotika golongan penisilin. Demikian halnya dengan hasil penelitian Cuevas et al (2004) bahwa terdapat peningkatan resistensi Staphylococcus koagulase negatif terhadap eritromisin hingga tahun 2002 mencapai 63\% (11).

Secara umum, hasil uji resistensi bakteri Staphylococcus koagulase negatif terhadap antibiotika menunjukkan peningkatan resistensi bakteri terhadap antibiotika. Hasil penelitian ini menunjukkan tingkat resistensi bakteri terhadap antibiotika maksimal hanya $79 \%$ yaitu terhadap antibiotika netilmisin, amikasin, dan norfloksasin. Peningkatan tingkat resistensi bakteri dipercepat oleh terapi antibiotika yang tidak rasional, hanya berdasarkan pengalaman empirik dan tidak berdasarkan hasil uji resistensi terhadap antibiotika.

Pada penelitian ini masih terdapat peningkatan resistensi bakteri Staphylococcus koagulase negatif terhadap antibiotika tetrasiklin, doksisiklin, dan kloramfenikol. Fenomena yang sama terjadi pada hasil SENTRY Antimicrobial Surveillance Program tahun 1997 bahwa sensitivitas Staphylococcus koagulase negatif terhadap tetrasiklin / kloramfenikol di Amerika Serikat dan Kanada masih tinggi yaitu $79,5 \% / 88,5 \%$ dan $81,8 \% / 84,6 \%$ (10). Selain itu hasil penelitian Cuevas et al (2004) juga menunjukkan peningkatan sensitivitas Staphylococcus koagulase negatif terhadap antibiotika kloramfenikol hingga mencapai $91,1 \%$ pada tahun 2002 (11). Perlu observasi dan penelitian lebih lanjut untuk menjawab pertanyaan mengapa fenomena ini dapat terjadi. Dugaan sementara, hal ini disebabkan oleh jarangnya penggunaan antibiotika golongan tetrasiklin dan kloramfenikol tersebut sebagai terapi penyakit infeksi bacterial, khususnya di rumah sakit. 


\section{KESIMPULAN}

Staphylococcus koagulase negatif merupakan bakteri yang paling sering ditemukan dari sampel darah penderita yang dikirim di Laboratorium Mikrobiologi FK Unibraw / RSSA pada tahun 2000-2001 dan tahun 2004-2005 dan secara statistik terdapat peningkatan resistensi Staphylococcus koagulase negatif terhadap antibiotika golongan beta laktam. Namun demikian terdapat peningkatan resistensi terhadap antibiotika tetrasiklin, doksisiklin, dan kloramfenikol. Sedangkan resistensi bakteri tersebut terhadap antibiotika amikasin dan netilmisin tetap tinggi.

\section{SARAN}

Perlu dilakukan penelitian lebih lanjut mengenai asal infeksi Staphylococcus koagulase negatif dari sampel darah tersebut merupakan infeksi dari komunitas atau infeksi nosokomial. Selain itu perlu dilakukan penelitian berkesinambungan mengenai pola bakteri dan resistensinya terhadap antibiotika.

\section{DAFTAR KEPUSTAKAAN}

1. Giusti MD, Pacifico L, Tufi D, Panero A, Boccia A, and Chiesa C. Phenotypic Detection of Nosocomial mecA-positive Coagulase Negative Staphylococci from Neonates. Journal of Antimicrobial Chemotherapy 1999;44: 351-358

2. Graham JC, Murphy OM, Stewart D, Kearns AM, Galloway A, and Freeman R. Comparison of PCR Detection of mecA with Methicillin and Oxacillin Disc Susceptibility Testing in Coagulase-Negative Staphylococci. Journal of Antimicrobial Chemotherapy 2000; 45: 111-113.

3. Burnie JP, Naderi-Nasab M, Loudon KW, and Matthews RC. An Epidemiological Study of Blood Culture Isolates of Coagulase-Negative Staphylococci Demonstrating Hospital-Acquired Infection. J.Clin.Microbiol 1997; 35(7): 1746-1750

4. Baron EJ, Peterson LR, Finegold SM. Methods for Testing Antimicrobial Effectiveness. Bailey \& Scott's Diagnostic Microbiology $9^{\text {th }}$ ed. Missouri: Mosby; 1994; 168-188.

5. Mahoudeau I, Delabranche X, Prevost G, Mointeil H, and Piemont Y. Frequency of Isolation of Staphylococcus Intermedius from Humans. J.Clin.Microbiol 1997; 35(8): 2153-2154.

6. Tenover FC, Jones RN, Swenson JM, Zimmer B, McAllister S, and Jorgensen JH. Method for Improved Detection of Oxacillin Resistance in Coagulation-Negative Staphylococci: Results of a Multicenter Study. J.Clin Microbiol 1999; 37(12): 4051-4058.

7. Kawamura Y, Hou X-G, Sultana F, Hirose G, Miyake M, Shu S-E, and Ezaki T. Distribution of Staphylococcus Species among Human Clinical Specimens and Emended Description of Staphylococcus caprae. J.Clin.Microbiol 1998; 36(7): 2038-2042.

8. Horstkotte MA, Knobloch JK-M, Rohde H, Dobinsky S, and Mack D. Rapid Detection of Methicillin Resistance in Coagulation-Negative Staphylococci with the VITEK2 System. J.Clin.Microbiol 2002; 40(9): 3291-3295.

9. Lilik Zuhriyah. Gambaran Bakteriologis Tangan Perawat (Bacteriological Descriptions of Nurses's Hand). Jurnal Kedokteran Brawijaya 2004; XX (1): 53-56.

10. Pfaller MA, Jones RN, Doem GV, Kugler K, and Group SP. Bacterial Pathogens Isolated from Patients with Bloodstream Infections Frequencies of Occurrence and Antimicrobial Surveillance Program (United States and Canada). Antimicrobial Agents and Chemotherapy 1998; 42(7): 1762-1770.

11. Cuevas O, Cercenado E, Vindel A, Guinea J, Sanchez-Conde M, Sanches Somolinus M, Bouza E, and Spanish group for the study of Staphylococcus. Evolution of the Antimicrobial Resistance of Staphylococcus spp. In Spain: Five Nationwide Prevalence Studies, 1986 to 2002. J.Antimicrobial Agents and Chemotherapy 2004; 48(11): 4240-4245. 